Article

\title{
Savings and Loans Information System Design Method Using Web-Based User Centered Design (UCD) on Cooperative gem Bakti Nusantara
}

\author{
Dicky Karuna Arisandy ${ }^{l}$, Rudy Arijanto $^{2}$, \\ ${ }^{12}$ Buddhi Dharma University, Information Systems, Banten, Indonesia
}

\begin{tabular}{|c|c|}
\hline SUBMISSION TRACK & 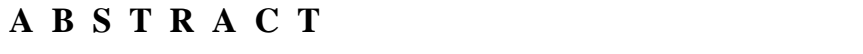 \\
\hline $\begin{array}{l}\text { Received } 11 \text { December 2018; } \\
\text { Revised } 20 \text { December 2018; } \\
\text { Accepted } 10 \text { February } 2019 ; \\
\text { Available online } 20 \text { February } 2019\end{array}$ & \multirow{5}{*}{$\begin{array}{l}\text { Savings and Loan Applications Using Web Based User } \\
\text { Centered Design aims to facilitate savings and loan } \\
\text { transactions with effective and efficient, from the user side, } \\
\text { the user can find out the data member in the form of total } \\
\text { deposits and loans with easy access. After doing research } \\
\text { Cooperative gem Bakti Nusantara, savings and loan process } \\
\text { often experience delays due to reports that the old data } \\
\text { collection and input process is slow. Which was made based } \\
\text { saving web application to overcome the problems of savings } \\
\text { and loan owned, it is expected that these applications and the } \\
\text { cooperative members can easily find out information about } \\
\text { savings and loans, and as well as to increase the number of } \\
\text { new members. }\end{array}$} \\
\hline KEYWORDS & \\
\hline $\begin{array}{l}\text { Applications, Savings and Loans, Computers, } \\
\text { Web }\end{array}$ & \\
\hline CORRESPONDENCE & \\
\hline $\begin{array}{l}\text { Phone: } 085774600007 \\
\text { E-mail: dickybond888@gmail.com }\end{array}$ & \\
\hline
\end{tabular}

\section{PRELIMINARY}

Implementation of information systems in a company can make a job more to be effective and efficient, but it takes also the outstanding service quality, and can meet the needs of the company. To achieve these requirements then the required means of support is a computerized system.

Electronic computer is a tool that consists of the top command input, input processing tools and equipment that provide outputs which provide information and works automatically [1]. And the cooperative is a container that can help people, especially small and medium communities. Cooperatives play an important role in the economic growth of the community such as micro-credit activities that offer lending and deposit the money to the public in order to invite the public in saving on. so that people can save their money than that in terms of lending, people can loan to the cooperative with very little interest to establish a business or business to be desired.

In Sejahtera Bersama Cooperative system, there are several issues to be analyzed, such as the absence of a system to facilitate the performance of staff in the process of savings and loan cooperatives and frequent occurrence of errors in the reporting process. So the lack of effectiveness in the conduct of savings and checking reports.

\section{METHOD}

Methods used include 2 (two) parts, namely data collection methods and design method.

\section{Method of collecting data}

\section{a. Literature review}

Methods A literature study by collecting and studying material from 
several sources, such as the Internet media, journals, and some reference books related to the system to be built.

b. questionnaires

This method was conducted to determine the level of satisfaction of users of the application if the application has been able to address user needs or the need for additional features.

\section{c. Interview}

This method is used to obtain information on the information about the savings and loan, procedures and organization in order to conclude the information.

\section{Design method}

The design method used is the Savings and Loans Information System Using Web-Based User Centered Design Methods.

Reveal UCD is the user as the center of the system development process, and the purpose / nature, context and environment systems are all based on the user experience [2].

Reveal Concept of UCD is the user as the center of the system development process, and the purpose/nature, context and environment systems are all based on the user experience [3]. The process of Method User Centered Design (UCD) based on ISO 92412102010 there are five processes, namely as figure 1 below.

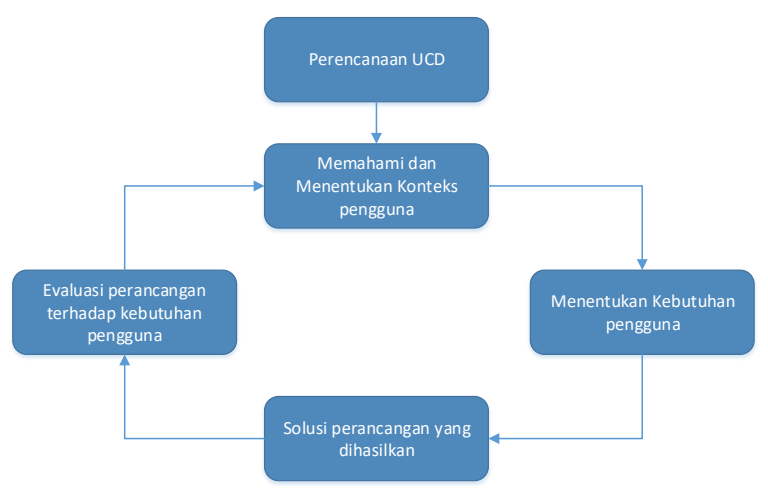

Fig. 1 UCD
1. planning UCD

At this stage, a meeting with the cooperative's author discusses the development of the system and work procedures or the flow of savings and loans.

2. Understand and determine the user's context

Identify the person who will use the application. This will be explained for what and under what conditions they will use the product.

3. Determining the needs of users Identify user needs and the needs of cooperative management.

4. The resulting design solution

Construct design as the solution of the application being analyzed.

5. Evaluation of the design to the needs of users

To evaluate the design done whether the purpose of the user and the cooperative has been reached.

\section{RESULTS}

After doing research on cooperative gem Bakti Nusantara then it may be a solution in the form of Savings and Loans Information System Web-Based User Centered Design Method Using the following display design results in the application, namely:

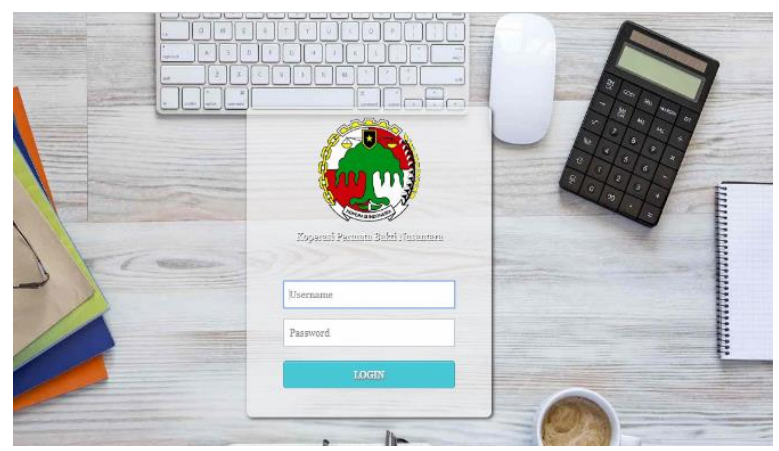

Fig 1. Login Menu Display

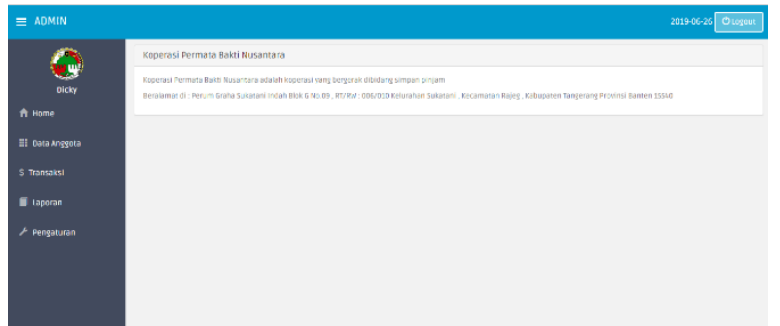


Fig 2. Menu Display Administrator

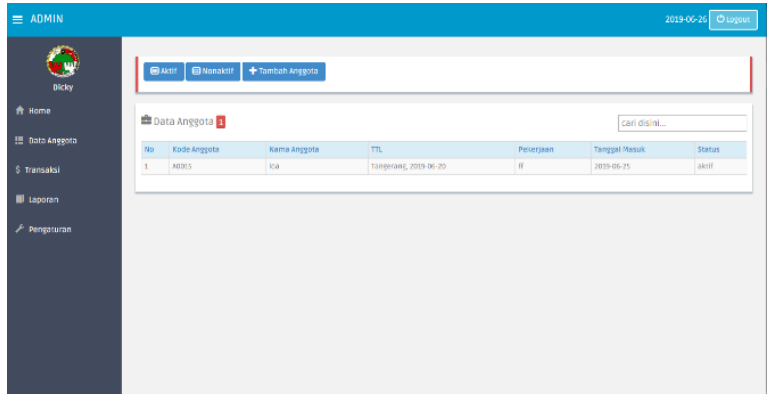

Fig 3. Member Data Menu Display Administrator

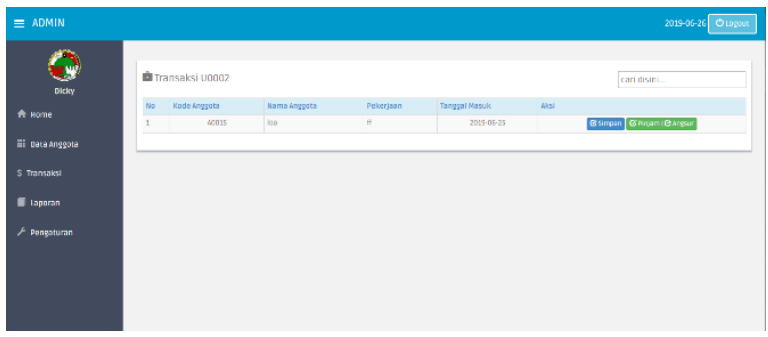

Fig 4. Transaction Menu Display Save and Loan Administrator

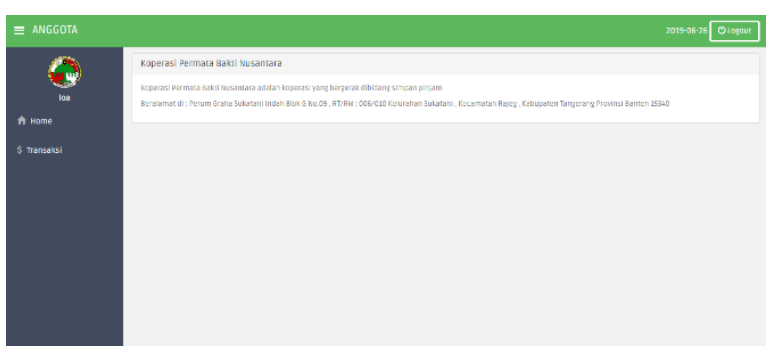

Fig 5. Main Menu Display Member

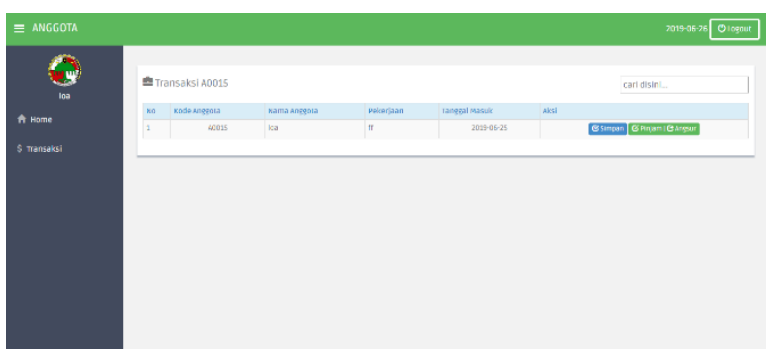

Fig 6. Member Transaction Menu Display

\section{CONCLUSION}

1. From the savings and loan information system using the web-based User Centered Design (UCD) this enables savings and loan transactions as well as assisting members in checking deposits and borrowings under way.
2. Savings and loan application is made to the Cooperative Bakti Nusantara gem can be used in real - time so it is very easy to determine changes or updates from the savings and loan system

3. The savings and loan application design using the User Centered Design as a reference in making the application. 


\section{REFERENCE}

[1] A. Susanto, "Pengenalan komputer," 2009. [Online]. Available: https://ilmukomputer.org/wp-content/uploads/2010/03/arief_pengenalankomputer.pdf. [Accessed 0905 20].

[2] R. M. Simatupang, "Penerapan Metode User Centered Desing Untuk perancangan aplikasi radio streaming berbasis web," 2014.

[3] Amborowati, " Rancangan Sistem Pameran Online menggunakan metode UCD( User Centered Design )," 2012.

\section{BIOGRAPHY}

Dicky Karuna Arisandy Graduated in Studies Program Information System (S1), 2019.

Rudy Arijanto Graduated in Studies Program Information Management and Computer STMIK (S1) Bina Nusantara and also Informatics (S2) STTI Benarif, now serving as Dean of the Faculty of Science and Technology at the University of Buddhi Dharma. 